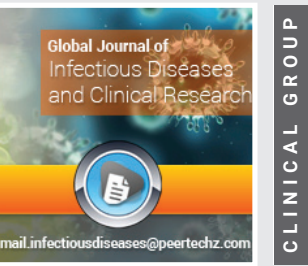

\title{
Febrile consumptive syndrome after prostatectomy
}

\author{
Ana Margarida Barrigó Fernandes Bernardo*, Susana \\ Escária and Sara Correia \\ Medicine 2 Department, Hospital Espírito Santo de Évora, Faculty of Medicine, University of Lisbon, \\ Portugal
}

Received: 21 January, 2020

Accepted: 27 February, 2020

Published: 28 February, 2020

*Corresponding author: Ana Margarida Barrigó Fernandes Bernardo, MD, Medicine 2 Department, Hospital Espírito Santo de Évora, Faculty of Medicine, University of Lisbon, Portugal, Tel: +351961339791;

E-mail: ana.mfbernardo@gmail.com

https://www.peertechz.com

Check for updates

\section{Introduction}

A 75-year-old male patient came to the emergency department, referring high fever with nocturnal predominance and profuse sweating. He also referred asthenia, anorexia, and weight loss of $20 \mathrm{~kg}$ in the past month, with onset after prostatectomy due to a benign prostatic hyperplasia. He had a previous history of chronic lymphocytic leukemia and type 2 Diabetes mellitus.

The initial observation at the Emergency Department revealed a tympanic temperature of $39^{\circ} \mathrm{C}$ with no other changes. Laboratory tests showed thrombocytopenia, hyperlactacidemia, and increased inflammatory markers (table 1). On the chest $X$-ray, a diffuse interstitial enhancement was identified. He was admitted to the Medical Ward assuming a febrile consumptive syndrome of unknown etiology.

Table 1: Laboratory tests on admission.

\begin{tabular}{c|c} 
CRP & $22.1 \mathrm{mg} / \mathrm{dL}$ \\
\hline Platelets & $75000 / \mu \mathrm{L}$ \\
\hline Glycemia & $254 \mathrm{mg} / \mathrm{dL}$ \\
\hline Lactate & $5.2 \mathrm{mmol} / \mathrm{L}$ \\
\hline
\end{tabular}

The cardiac ultrasound showed no changes and the wholebody CT scan presented a lung reticulonodular pattern with no cavities (Figure 1).

On consulting the prostate histological examination report, we were surprised by the presence of changes suggestive of necrotizing granulomatous prostatitis with identification of acid-alcohol resistant bacillae and thereafter, the blood culture showed the presence of Mycobacterium tuberculosis.
Figure 1: Thoracic image of the CT scan showing reticulonodular pattern.

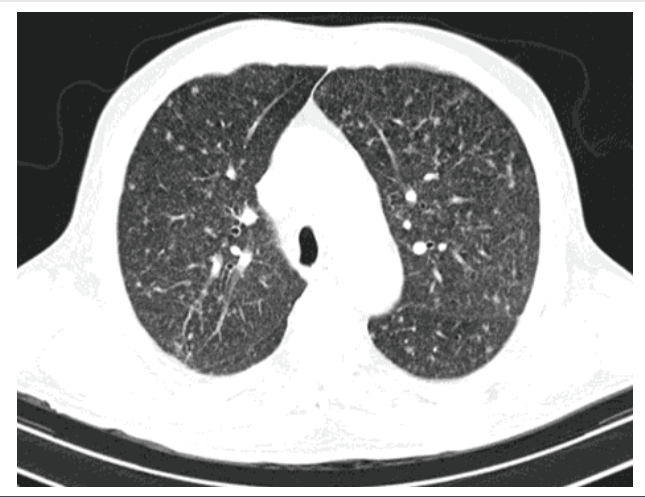

Figure 1: Thoracic image of the CT scan showing reticulonodular pattern

\section{Discussion}

The diagnosis was Prostatic Tuberculosis with hematogenous dissemination.

The patient was started on antibacillary therapy and Piperacillin/Tazobactam, and showed clinical improvement towards a full recovery.

Tuberculosis is an infectious disease with a high worldwide rate of morbidity and mortality, being associated with situations of immunosuppression. It generally presents with unspecific symptoms that can often lead to a delay in its diagnosis.

Prostatic tuberculosis is a rare clinical entity, which can go unnoticed. In this case, the lack of a correct diagnosis before the prostatectomy resulted in the hematogenous dissemination of the bacillae, leading to an infection difficult to control. 
The importance of this case disclosure is due to its rarity and severity and shows the importance of considering the diagnosis of urogenital tuberculosis in patients presenting with urinary symptoms and prostatic imagiologic changes.
This patient is from Alentejo, an interior region of Portugal, which, despite being a developed country, has a considerable prevalence of tuberculosis.
Discover a bigger Impact and Visibility of your article publication with

Peertechz Publications

Highlights

* Signatory publisher of ORCID

* Signatory Publisher of DORA (San Francisco Declaration on Research Assessment)

* Articles archived in worlds' renowned service providers such as Portico, CNKI, AGRIS, TDNet, Base (Bielefeld University Library), CrossRef, Scilit, J-Gate etc.

* Journals indexed in ICMJE, SHERPA/ROMEO, Google Scholar etc.

* OAI-PMH (Open Archives Initiative Protocol for Metadata Harvesting)

* Dedicated Editorial Board for every journal

* Accurate and rapid peer-review process

* Increased citations of published articles through promotions

* Reduced timeline for article publication

Submit your articles and experience a new surge in publication services (https://www.peertechz.com/submission).

Peertechz journals wishes everlasting success in your every endeavours.

Copyright: @ 2020 Fernandes Bernardo AMB, et al. This is an open-access article distributed under the terms of the Creative Commons Attribution License, which permits unrestricted use, distribution, and reproduction in any medium, provided the original author and source are credited. 